International Research Journal of Diabetes and Metabolism (DOI:10.28933/IRJDM)

\title{
To characterize the sociodemographic, clinical, therapeutic and quality of life of users of the Unified Health System with Diabetes
} mellitus

\author{
Silva L.L.S.B.'; Gonzaga I.A.A.S.2; Santos E.K.M.³ Silva L.N.M.4; Santos E.C.B.5
}

${ }^{1}$ Acadêmica do Curso de Graduação em Enfermagem da Universidade Federal de Pernambuco. Brasil; 2 ,3Enfermeiras pela Universidade Federal de Pernambuco. Brasil. 4Acadêmica do Curso de Graduação em Enfermagem da Universidade Federal de Pernambuco, 5Doutora em Enfermagem pela USP. Professora Adjunta da Universidade Federal de Pernambuco. Brasil. Orientadora.

\begin{abstract}
Introduction: Descriptive study with a quantitative approach carried out between October 2015 and October 2016. Sampling was about 100 people with diabetes. Objective: To characterize the sociodemographic, clinical, therapeutic and quality of life of users of the Unified Health System with Diabetes mellitus in a Basic Health Unit (BHU) of the Rural Zone of the city of Vitória de Santo Antão. Methods: Two questionnaires, sociodemographic, clinical and therapeutic, and DQUOL-BRASIL, both validated, were used. Results and discussion: Higher prevalence of female people $(75 \%)$. Of the investigators $(51 \%)$ were not able to report their type of diabetes, the medication was obtained in the BHU (44\%) as well as the follow-up (78\%). (44\%) did not receive the blood glucose strips, and (92\%) did not participate in educational programs. Regarding the quality of life or impact domain, the highest mean was obtained (32.05) and the lowest for the sale of diabetes problems (6.66). Conclusion: It is concluded that the results obtained contribute to increase the knowledge about the factors studied, since knowing a population makes possible the development of effective health actions, considering the local specificities.
\end{abstract}

Keywords: Diabetes Mellitus, Health Profile, Quality of Life, Rural Areas.
*Correspondence to Author:

Silva L.L.S.B

Acadêmica do Curso de Graduação em Enfermagem da Universidade Federal de Pernambuco. Brasil

How to cite this article:

Silva L.L.S.B.; Gonzaga I.A.A.S.; Santos E.K.M.; Silva L.N.M.; Santos E.C.B. To characterize the sociodemographic, clinical, therapeutic and quality of life of users of the Unified Health System with Diabetes mellitus.International Research Journal of Diabetes and Metabolism, 2018, $1: 5$

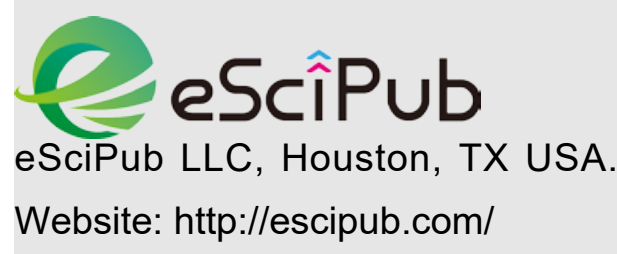

